\title{
Cemaran Mikroba Pada Telur Penyu Sisik (Eretmochelys imbricata) di Pulau Kelapa Dua, Taman Nasional Laut Kepulauan Seribu, DKI Jakarta
}

\author{
Mukti Ageng Wicaksono ${ }^{1}$, Fitriani Nurhasanah ${ }^{2}$, Dewi Elfidasari ${ }^{1}$, \\ Irawan Sugoro ${ }^{3}$ \\ ${ }^{1}$ Program Studi Biologi, Fakultas Sains dan Teknologi, Universitas Al Azhar Indonesia, Jakarta \\ ${ }^{2}$ Program Studi Biologi, Fakultas Sains dan Teknologi, UIN Syarif Hidayatullah, Jakarta \\ ${ }^{3}$ Pusat Aplikasi Isotop dan Radiasi-BATAN, Jakarta
}

Penulis untuk Korespondensi/Email: agengw1@gmail.com

\begin{abstract}
Abstrak - Penyu sisik (Eretmochelysimbricata) merupakan salah satu jenis penyu yang hidup di perairan Indonesia. Populasi penyu sisik saat ini terus mengalami penurunan. Salah satu faktor penyebabnya adalah keberadaan mikroba pencemar pada telur penyu. Tujuan dari penelitian ini adalah mengetahui cemaran mikroba pada telur penyu sisik di Pulau Kelapa Dua. Analisis secara mikrobiologi meliputi total bakteri, jamur, coliform, Enterobacter, dan SalmonellaShigella dilakukan terhadap sampel telur segar dan telur gagal menetas. Hasil analisis menunjukkan bahwa semua sampel tercemar mikroba yang mempengaruhi daya tetas telur. Sampel cangkang telur segar memiliki total bakteri 9,60x10 ${ }^{5}$ CFU/butir, jamur $2,35 \times 10^{5}$

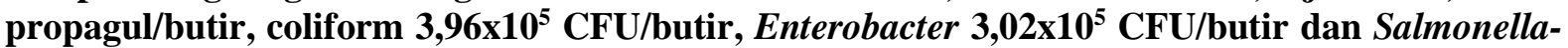
Shigella 1,68x10 $\mathrm{CFU} / \mathrm{butir}$, sedangkan hasil analisis dari sampel isi telur segar diperoleh total

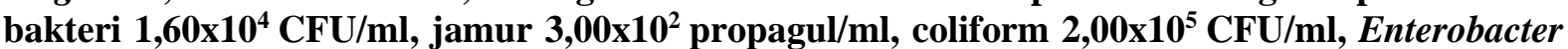
$1,20 \times 10^{5} \mathrm{CFU} / \mathrm{ml}$ dan Salmonella-Shigella $1,46 \times 10^{5} \mathrm{CFU} / \mathrm{ml}$. Hasil analisis dari sampel cangkang telur gagal menetas diperoleh total bakteri $7,20 \times 10^{6} \mathrm{CFU} /$ butir, jamur $1,92 \times 10^{5}$ propagul/butir,

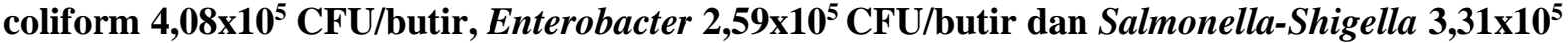
CFU/butir, sedangkan hasil analisis dari sampel isi telur gagal menetas diperoleh total bakteri

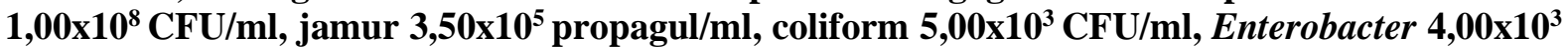
CFU/ml dan Salmonella-Shigella 3,00x10 ${ }^{3} \mathrm{CFU} / \mathrm{ml}$.
\end{abstract}

Kata Kunci - Penyu sisik, telur, Pulau Kelapa Dua, cemaran mikroba.

Abstract - Hawksbill (Eretmochelysimbricata) is one of the turtle species that live in Indonesian waters. The current population of hawksbill continues to decline. One of the contributing factors is the presence of contaminant microbes in turtle eggs. The purpose of this research is to know microbial contamination on hawksbill eggs in Kelapa Dua Island. Microbiological analyzes included total bacteria, fungi, coliform, Enterobacter, and Salmonella-Shigella were performed on fresh egg samples and eggs failed to hatch. The results showed that all samples were contaminated with microbes affecting the hatchability of the eggs. Fresh eggshell samples had total bacteria of $9.60 \times 105 \mathrm{CFU} /$ grains, $2.35 \times 105$ fungus propagules/grains, coliform 3.96x105 CFU/grains, Enterobacter 3.02x105 CFU/grains and Salmonella-Shigella 1.68x105 CFU/grains, while yield analysis of fresh egg contents samples obtained total bacteria 1.60x104 CFU/ml, mushrooms 3,00x102 propagules/ml, coliform 2.00x105 CFU/ml, Enterobacter 1,20x105 CFU/ml and Salmonella-Shigella 1,46x105 CFU/ml. Results of analysis of eggshell samples failed to hatch obtained total bacteria 7.20x106 CFU/grains, $1.92 \times 105$ fungi propagules/grains, coliform 4.08x105 CFU/grains, Enterobacter 2.59x105 CFU/grains and Salmonella-Shigella 3.31x105 CFU/while the results of the analysis of the sample of egg contents failed to hatch obtained total bacteria $1.00 \times 108 \mathrm{CFU} / \mathrm{ml}$, mushrooms $3,50 \times 105$ propagules $/ \mathrm{ml}$, coliform 5.00x103 CFU/ml, Enterobacter 4,00x103 CFU/ml and Salmonella-Shigella 3, 00x103 CFU/ml.

Keywords - Hawksbill, Egg, Kelapa Dua Island, microbial contamination 


\section{PENDAHULUAN}

Penyu merupakan salah satu jenis reptil yang dapat hidup dengan waktu yang sangat lama dan memiliki persebaran yang cukup luas di seluruh dunia. Terdapat tujuh spesies penyu yang hidup di dunia, enam diantaranya dapat ditemukan di perairan Indonesia. Keenam jenis penyu tersebut adalah Penyu Belimbing (Dermochelys coriacea), Penyu Sisik (Eretmochelys imbricata), Penyu Hijau (Chelonia mydas), Penyu Tempayan (Caretta caretta), Penyu Pipih (Natator depressa), dan Penyu Lekang (Lepidochelys olivaceae). Satu jenis penyu yang tidak ditemukan di perairan Indonesia adalah Penyu Kempi (Lepidochelys kempi). Penyu tersebut hanya ditemukan di perairan Amerika Latin (Janawi 2009).

Salah satu jenis penyu yang hidup di perairan Indonesia adalah Penyu sisik (Eretmochelys imbricata). Penyu sisik merupakan salah satu jenis penyu yang berukuran kecil. Ukuran tubuh penyu sisik dewasa lebih kecil dibandingkan dengan penyu hijau. Panjang tubuh penyu sisik dewasa berkisar antara 70 $90 \mathrm{~cm}$ dan bobot tubuh antara $40-90 \mathrm{~kg}$ (Nur, 2004). Karapas penyu sisik dewasa berbentuk oval atau elips, bagian pinggir karapas bergerigi, kecuali pada tukik (Syamsuni, 2006). Penyu sisik umumnya hidup di bagian laut yang tidak terlalu dalam, dekat daerah pantai peneluran dengan perairan laut yang ditumbuhi alga dan lamun juga hewan laut. Hewan laut seperti sponge menjadi makanan utama bagi penyu sisik (Spotilla 2004). Berbeda dengan penyu hijau (Chelonia mydas), penyu sisik umumnya bertelur di pulau-pulau kecil pada pantai yang tidak luas dengan tekstur pasir yang kasar dan bercampur pecahan batu karang dan cangkang moluska, sarangnya dangkal dekat dengan batas vegetasi pantai (Suwelo et al 1992).

Keberadaan penyu sisik di Indonesia terancam dalam kepunahan. Faktor kepunahan tersebut meliputi perburuan illegal, degradasi habitat, predasi dan penyakit (Lam 2006). Selain hal tersebut, faktor lainnya adalah keberadaan mikroorganisme pada telur, air laut, atau pasir. Bakteri dan jamur terbukti mengurangi keberhasilan penetasan telur penyu di seluruh dunia (Foti et al 2009). Phillot (2002) menyatakan bahwa jamur Fusarium oxysporum dan Fusarium solani pada sampel telur penyu sisik yang gagal menetas di Australia merupakan penyebab utama rendahnya keberhasilan penetasan telur. Hal ini dipertegas oleh Estika (2013) dalam hasil penelitiannya menyatakan bahwa jumlah mikroorganisme dapat mempengaruhi keberhasilan penetasan telur penyu.

Salah satu tempat peneluran penyu sisik di Indonesia adalah Pulau Kelapa Dua, Kepulauan Seribu, DKI Jakarta. Pulau ini sejak lama menjadi salah satu tempat peneluran penyu sisik, namun intensitas peneluran penyu sisik di pulau ini terus menurun akibat pencemaran laut dan degradasi habitat. Selain itu juga tingkat penetasan telur yang rendah pada sarang semialami yang dibuat untuk melindungi telur dari perburuan. Diduga rendahnya tingkat penetasan akibat adanya cemaran mikroorganisme pada telur. Penelitian ini dilakukan untuk menganalisis keberadaan mikroorganisme pencemar pada cangkang telur, pasir, dan isi telur penyu sisik (Eretmochelys imbricata) yang diperoleh dari Pulau Kelapa Dua, Taman Nasional Laut Kepulauan Seribu, DKI Jakarta. Hasil penelitian ini diharapkan dapat memberikan tambahan informasi terkait faktorfaktor penyebab rendahnya penetasan telur penyu pada sarang semi-alami.

\section{METODOLOGI}

\section{Objek Penelitian}

Objek penelitian ini adalah sampel telur penyu sisik (Eretmochelys imbricata) yang diperoleh dari Pulau Kelapa Dua, Taman Nasional Laut Kepulauan Seribu, DKI Jakarta. Telur berasal dari sarang semi-alami yaitu sampel telur yang gagal menetas (TB), sampel telur segar yang diperoleh dari sarang alami (TS) dan sampel pasir dari sarang semi-alami (P). Kondisi telur pada TB maupun TS masih utuh dengan isi telurnya. Sampel telur segar (TS) diambil saat induk penyu bertelur di sarang alami.

\section{Waktu dan Tempat Penelitian}

Analisa mikrobiologi dilakukan di Laboratorium Pusat Aplikasi Isotop dan Radiasi - BATAN pada bulan Februari - Mei 2014. 


\begin{abstract}
Alat dan Bahan
Alat yang digunakan adalah cawan petri, mikropipet, autoklaf, penangas, Laminar Air Flow, mikroskop dan inkubator. Bahan yang digunakan untuk analisa diantaranya media PCA, SDA, Mac Conkey agar, SS, EMB agar, $\mathrm{NaCl}$ 0,85\%, akuades, alkohol $70 \%$.
\end{abstract}

\section{Tahap Penelitian}

Penelitian ini dilakukan dengan 2 tahap yaitu identifikasi telur, dan enumerasi (bakteri, jamur, coliform, Enterobacter, dan SalmonellaShigella). Parameter yang diukur meliputi jumlah bakteri total, jumlah jamur total, jumlah coliform.

\section{Identifikasi Telur}

Identifikasi telur dilakukan dengan pengamatan langsung berdasarkan kondisi telur penyu yang digunakan sebagai sampel, meliputi cangkang dan isi telur.

\section{Persiapan Sampel}

Sampel dibedakan menjadi sampel cangkang, isi telur dan pasir. Persiapan yang dilakukan untuk sampel cangkang yaitu, cangkang telur direndam dalam gelas piala berisi larutan $\mathrm{NaCl}$ $0,85 \%$ steril hingga cangkang telur tenggelam, kemudian ditambahkan lagi larutan $\mathrm{NaCl}$ $0,85 \%$ hingga volume larutan $80 \mathrm{ml}$ dan larutan hasil rendaman cangkang dipindahkan ke tabung. Sampel isi telur disiapkan dengan cara menggunting cangkang kemudian isi telur (albumin dan yolk) dipipet sebanyak $1 \mathrm{ml}$ dan diletakkan dalam mikrotube steril. Pada sampel pasir, ditimbang sebanyak 1,03 g kemudian dimasukkan ke dalam tabung steril dan ditambahkan larutan $\mathrm{NaCl} \quad 0,85 \%$ hingga volume larutan menjadi $5 \mathrm{ml}$.

\section{Enumerasi Mikroorganisme}

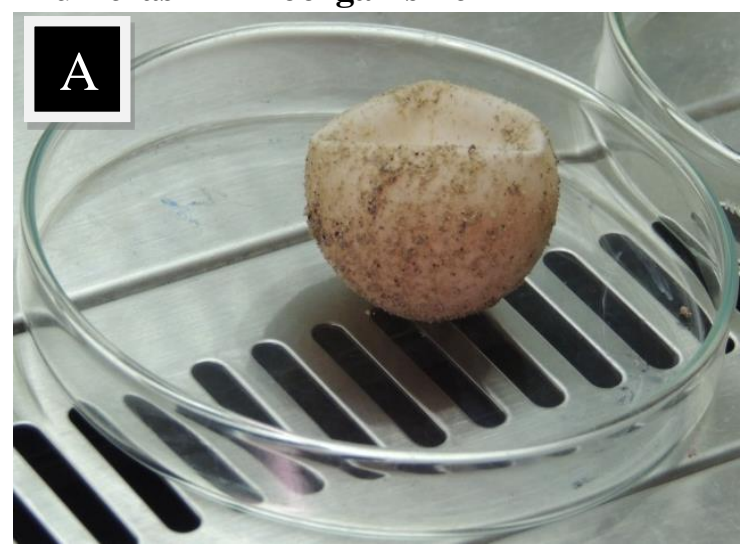

Enumerasi bakteri total, jamur, coliform, Enterobacter dan Salmonella-Shigella dilakukan dengan metode spread plate. Untuk enumerasi bakteri total, 5 jenis sampel yang telah disiapkan dibuat $3 \mathrm{x}$ pengenceran menggunakan larutan $\mathrm{NaCl} 0,85 \%$ steril. Sampel cangkang menggunakan sampel tanpa pengenceran $10^{\circ}$ lalu disebar pada masingmasing media yang digunakan. Sampel isi telur dan pasir pada media PCA dan SDA menggunakan sampel pengenceran $10^{0}-10^{-3}$, media MCA menggunakan sampel pengenceran $10^{-2}$, sedangkan media SS dan MBA menggunakan sampel pengenceran $10^{-1}$. Sampel-sampel selanjutnya diinkubasi selama 24 jam pada suhu ruang dan dilakukan penghitungan koloni.

\section{HASIL DAN PEMBAHASAN}

\section{Identifikasi Telur}

Sampel telur yang diambil dari sarang semialami (TB) bulat tidak sempurna, cangkang berwarna kecokelatan, dengan isi telur di dalamnya. Bau busuk yang menyengat tercium dari telur yang gagal menetas. Sampel telur segar (TS) berbentuk bulat sempurna, cangkang berwarna putih, dengan isi telur didalamnya. Lapisan kalsium pada cangkang telur TB telah mengalami pengikisan sehingga cangkang terlihat mengelupas dan menipis. Pengikisan lapisan kalsium pada telur TB terjadi akibat keberadaan jamur yang mengkonsumsi kalsium pada lapisan kulit telur (Phillot et al 2006). Sementara itu cangkang telur TS masih tebal dan tidak mengalami pengikisan sebab embrio belum menempel pada lapisan kalsium untuk dikonsumsinya saat masa inkubasi (Gans \& Gaunt 1969).

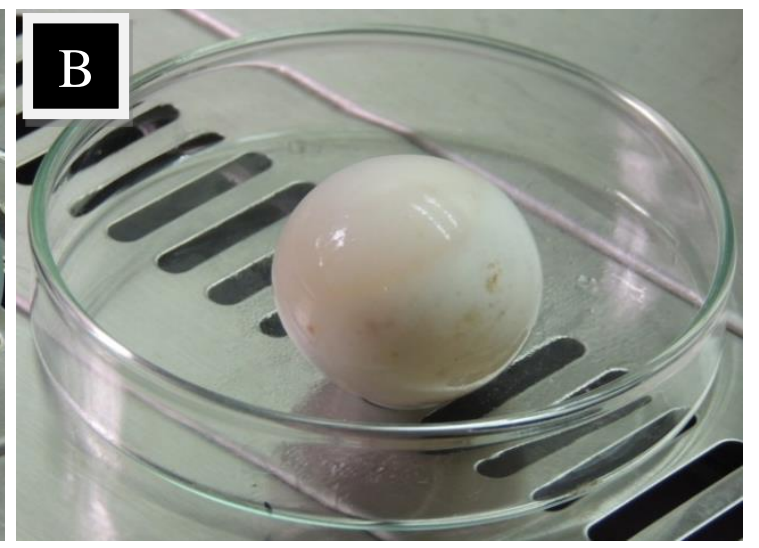

Gambar 1. A. Sampel telur TB B. Sampel telur TS 
Menurut Phillot (2002), cangkang semua telur penyu berwarna putih, berbentuk bulat, kledoik, dengan pori-pori kecil di seluruh cangkang yang memungkinkan untuk pertukaran gas pernapasan, uap air, dan panas dari lingkungan eksternal. Seperti telur penyu lainnya, telur penyu sisik mengandung poripori dengan berbagai ukuran untuk pertukaran gas dan penyerapan air. Pori-pori ini penting untuk kelangsungan hidup embrio, namun berpotensi menyebabkan kerentanan embrio terhadap infeksi bakteri dan jamur. Hal ini terjadi ketika usia telur memasuki masa akhir inkubasi, ukuran pori-pori menjadi lebih besar sehingga koloni bakteri dan jamur dapat masuk ke lapisan dalam telur (Al-Bahry et al., 2011).

\section{Enumerasi mikroorganisme}

Bakteri, jamur, coliform, Enterobacter dan Salmonella-Shigella berhasil diisolasi dari kelima jenis sampel yang dianalisis. Penghitungan koloni bakteri setiap sampel dilakukan pada media PCA. Hasil enumerasi bakteri setiap sampel dapat dilihat pada Gambar 2. Jumlah bakteri pada cangkang dan

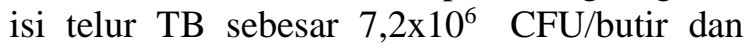
$1 \times 10^{8} \mathrm{CFU} / \mathrm{ml}$. Jumlah bakteri pada cangkang dan isi telur TS sebesar 9,6×10 $0^{5} \mathrm{CFU} /$ butir dan $1,6 \times 10^{4} \mathrm{CFU} / \mathrm{ml}$. Jumlah bakteri pada pasir dari sarang semi-alami $(\mathrm{P})$ sebesar $1,46 \times 10^{6}$ $\mathrm{CFU} / \mathrm{ml}$.

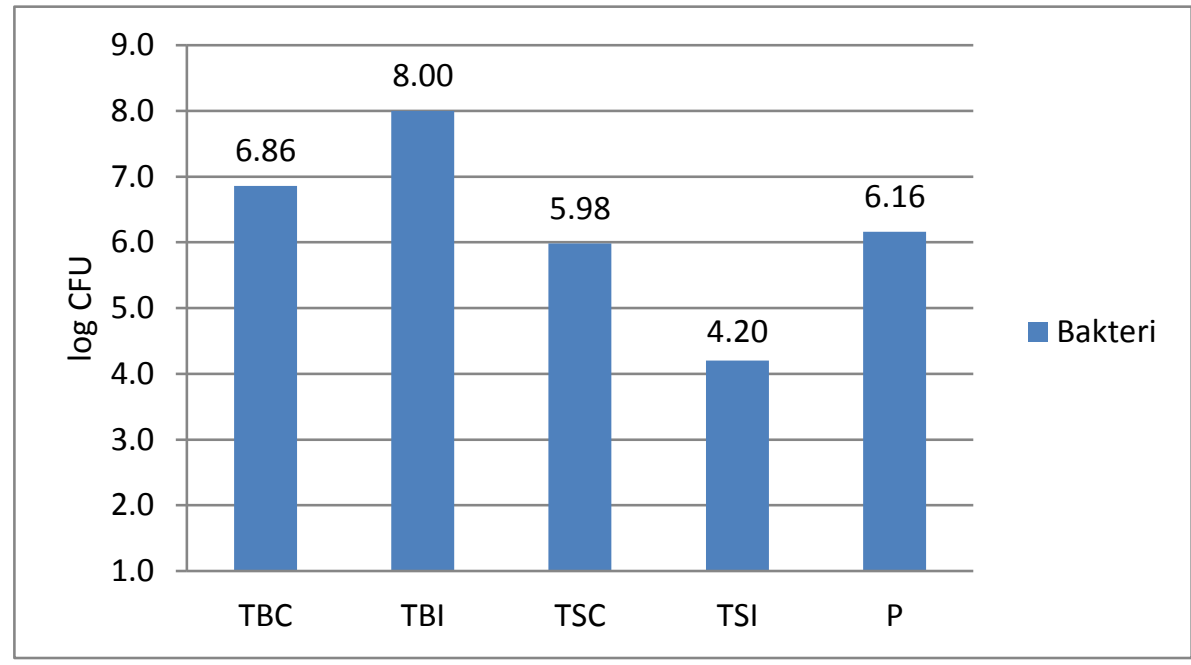

Gambar 2. Grafik Jumlah Bakteri Total.

Keterangan :

TB: Telur gagal menetas (C: Cangkang, I: Isi); TS: Telur segar (C: Cangkang, I: Isi); P: Pasir

Jumlah bakteri tertinggi dari 2 sampel TB terdapat pada isi telur sedangkan yang terendah Perbandingan jumlah koloni jamur total dari keseluruhan sampel terlihat jelas pada Gambar 3. Hasil penghitungan koloni jamur seluruh sampel pada media SDA menunjukkan jumlah koloni jamur pada cangkang dan isi telur TB sebesar $1,92 \times 10^{5}$ propagul/butir dan $3,5 \times 10^{5}$ adalah cangkang. Jumlah bakteri tertinggi dari 2 sampel TS terdapat pada cangkang sedangkan yang terendah adalah isi telur. Dari grafik jumlah bakteri total terlihat jelas bahwa sampel isi telur TB memiliki jumlah tertinggi diantara keseluruhan sampel.

propagul $/ \mathrm{ml}$. Jumlah koloni jamur pada cangkang dan isi telur TS sebesar $2,35 \times 10^{5}$ propagul/butir dan $3 \times 10^{2}$ propagul $/ \mathrm{ml}$. Jumlah koloni jamur pada pasir dari sarang semi-alami (P) sebesar $3,4 \times 10^{4} \quad$ propagul $/ \mathrm{ml}$ 


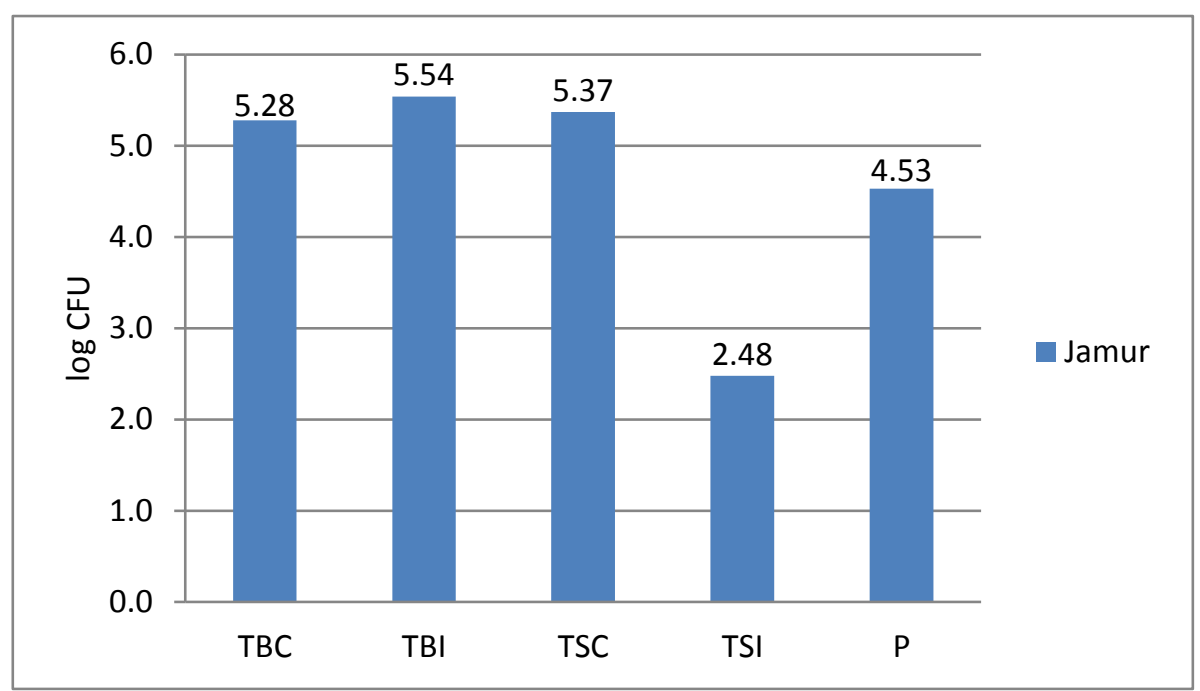

Gambar 3 Grafik Jumlah Jamur Total.

Jumlah koloni jamur tertinggi dari sampel TB terdapat pada isi telur sedangkan yang terendah adalah cangkang. Pada sampel TS, jumlah jamur tertinggi ada pada bagian cangkang dan yang paling terendah pada isi telur. Dari grafik jumlah jamur total terlihat jelas bahwa sampel isi telur TB memiliki jumlah tertinggi diantara keseluruhan sampel.

Koloni mikroorganisme yang juga terdapat pada seluruh sampel selain bakteri adalah coliform. Pengamatan dilakukan pada media MCA dari setiap sampel. Hasil enumerasi coliform pada masing-masing sampel menunjukkan hasil yang berbeda (Gambar 4). Jumlah coliform pada cangkang dan isi telur TB sebesar $4,08 \times 10^{5}$ CFU/butir dan $5 \times 10^{3}$
CFU/ml. Jumlah coliform pada cangkang dan isi telur TS sebesar $3,96 \times 10^{5} \mathrm{CFU} /$ butir dan $2 \times 10^{5} \mathrm{CFU} / \mathrm{ml}$. Jumlah coliform pada pasir dari sarang semi-alami $(\mathrm{P})$ sebesar $1,9 \times 10^{5}$ $\mathrm{CFU} / \mathrm{ml}$.

Jumlah coliform tertinggi dari sampel TB terdapat pada cangkang sedangkan yang terendah adalah isi telur. Pada sampel TS, jumlah coliform tertinggi ada pada bagian cangkang dan yang paling terendah pada isi telur. Dari grafik jumlah coliform total terlihat jelas bahwa sampel cangkang TB dan TS hampir memiliki tingkat cemaran coliform yang sama tinggi, begitu pula pada sampel isi telur TS dengan sampel P. Cemaran coliform terendah pada sampel isi telur TB.

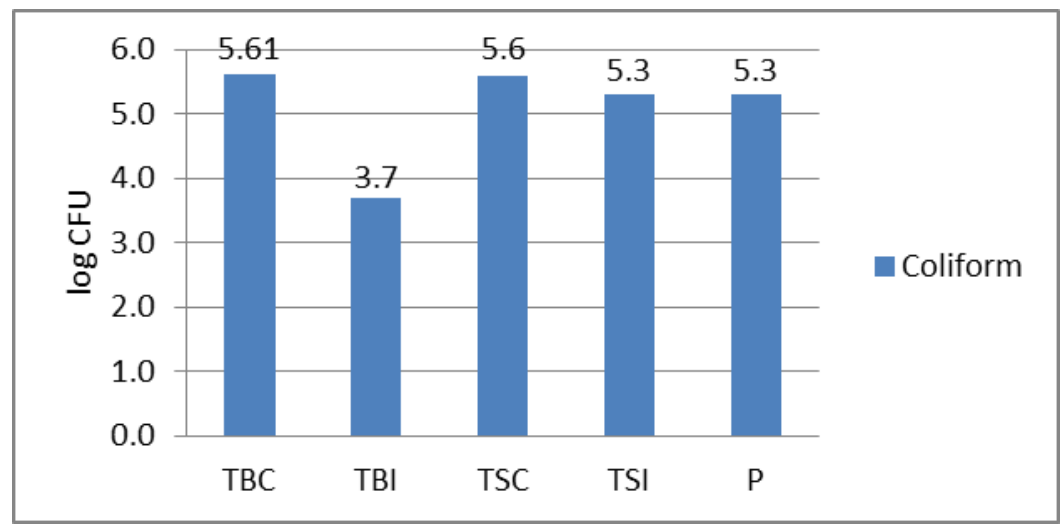

Gambar 5. Grafik Jumlah Coliform Total

Hasil penghitungan koloni Enterobacter seluruh sampel pada media EMB menunjukkan hasil yang berbeda (Gambar 6). Jumlah koloni Jumlah Enterobacter pada cangkang dan isi

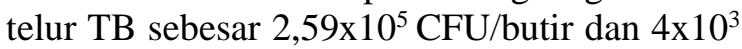

CFU/ml. Jumlah koloni Enterobacter pada cangkang dan isi telur TS sebesar $3,02 \times 10^{5}$

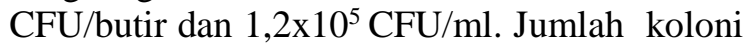
Enterobacter pada pasir dari sarang semi-alami (P) sebesar 3,5x10 ${ }^{4} \mathrm{CFU} / \mathrm{ml}$. 


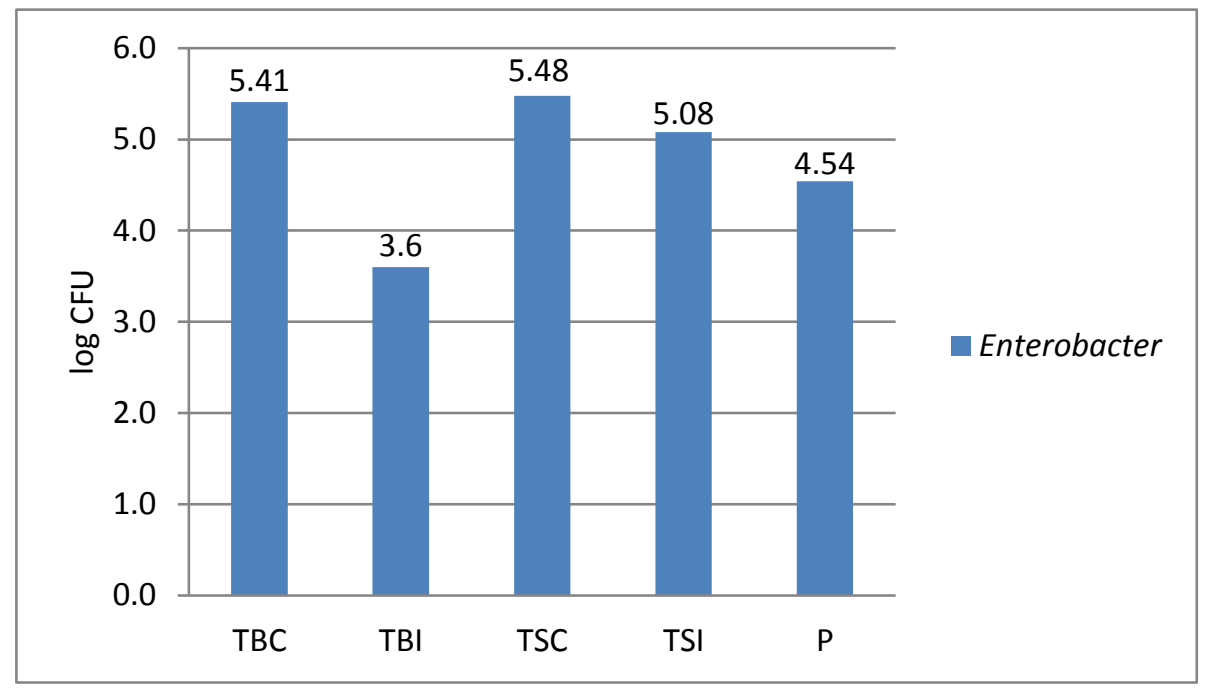

Gambar 6. Grafik Jumlah Entrobacter total

Jumlah Enterobacter tertinggi dari sampel TB terdapat pada cangkang sedangkan yang terendah adalah isi telur. Pada sampel TS, jumlah Enterobacter tertinggi ada pada bagian cangkang dan yang paling terendah pada isi telur. Dari grafik jumlah Enterobacter total terlihat jelas bahwa sampel TS memiliki cemaran lebih tinggi dibandingkan sampel TB dan P.

Hasil penghitungan total koloni pada media SSA untuk melihat adanya pertumbuhan bakteri Salmonella dan Shigella dan. Penghitungan total koloni pada media SSA dilakukan sebanyak dua kali, karena total koloni Shigella dapat dihitung setelah diinkubasi selama 24 jam, sedangkan total koloni Salmonella baru dapat dihitung setelah diinkubasi selama 48 jam. Hasil enumerasi koloni Shigella setiap sampel menunjukkan hasil yang berbeda (Gambar 7). Jumlah koloni Salmonella-Shigella pada cangkang dan isi telur TB sebesar $3,31 \times 10^{5}$ CFU/butir dan $3,00 \times 10^{3} \mathrm{CFU} / \mathrm{ml}$. Jumlah koloni SalmonellaShigella pada cangkang dan isi telur TS sebesar $1,68 \times 10^{5} \mathrm{CFU} / \mathrm{butir}$ dan $1,46 \times 10^{5} \mathrm{CFU} / \mathrm{ml}$. Jumlah koloni Salmonella-Shigella pada pasir dari sarang semi-alami $(\mathrm{P})$ sebesar $1,75 \times 10^{4}$ $\mathrm{CFU} / \mathrm{ml}$.

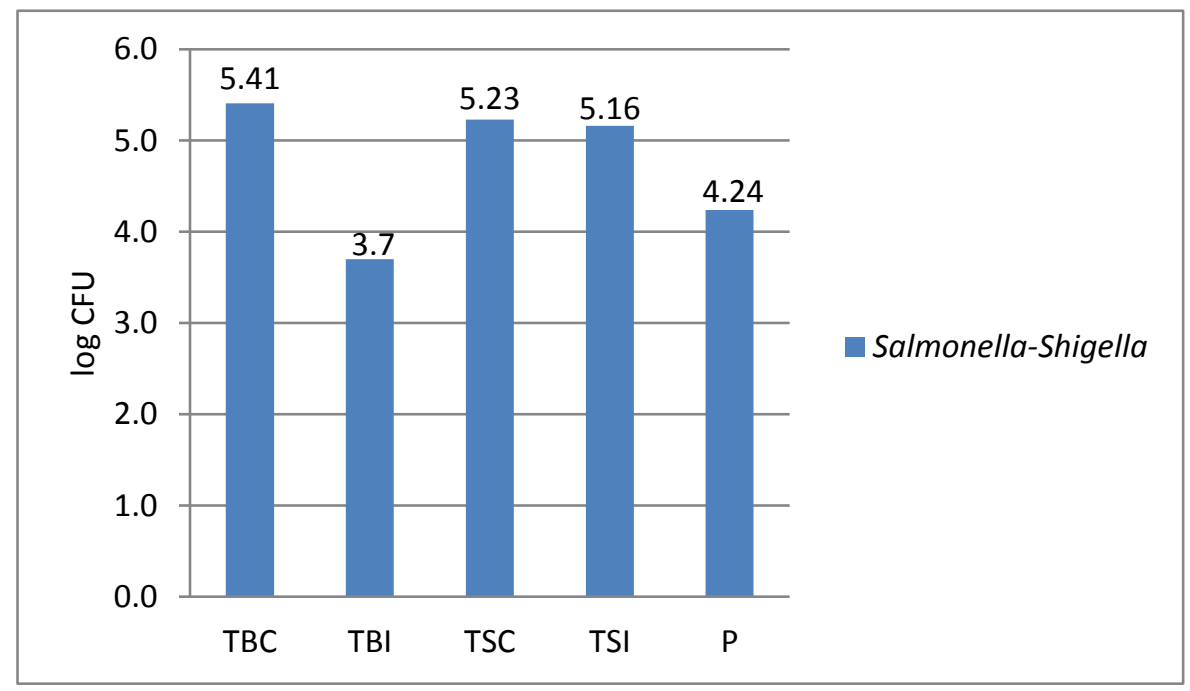

Gambar 7. Grafik jumlah Salmonella-Shigella total

Dari grafik jumlah koloni Salmonella-Shigella total terlihat jelas bahwa baik dari sampel TB maupun TS, jumlah koloni Salmonella-Shigella tertinggi pada sampel cangkang sedangkan yang terendah pada isi telur. Sampel cangkang dari TB memiliki tingkat cemaran yang lebih tinggi dibanding keseluruhan sampel, namun terlihat bahwa sampel TS (cangkang dan isi 
telur) memiliki cemaran total SalmonellaShigella tertinggi dibandingkan sampel TB (cangkang dan isi telur).

Hasil enumerasi menunjukkan bahwa seluruh sampel tercemar oleh mikroorganisme. Jumlah total bakteri, jamur dan coliform tertinggi berasal dari sampel TB, sedangkan jumlah total Enterobacter dan Salmonella-Shigella tertinggi berasal dari sampel TS. Keberadaan mikroorganisme pada telur penyu dapat berasal dari induk penyu maupun berasal dari lingkungan peneluran yang telah tercemar (Estika 2013).

Keberadaan mikroorganisme pada sampel TS diduga berasal dari induk penyu tersebut. Keene (2012) menyatakan bahwa sistem reproduksi induk penyu yang telah terinfeksi bakteri dan jamur, diduga dapat memindahkan mikroorganisme tersebut pada telur yang dihasilkannya. Sementara itu keberadaan mikroorganisme pada sampel TB diduga berasal dari induk maupun dari lingkungan penetasan atau sarang. Hal ini dibuktikan dengan adanya cemaran mikroorganisme pada sampel P yang berasal dari sarang semi-alami.

Kondisi sarang sangat berpengaruh terhadap keberhasilan penetasan telur penyu. Terdapat 2 faktor utama yang berpengaruh langsung terhadap keberhasilan menetas telur penyu selama masa inkubasi yaitu suhu dan kadar air dalam sarang (Rudiana et al. 2004). Kadar air berlebihan menyebabkan tingginya kelembaban. Kelembaban tinggi di lingkungan sarang meningkatkan pertumbuhan jamur dan bakteri sehingga dapat menutupi pori-pori cangkang telur. Penutupan ini mengganggu proses respirasi telur selanjutnya menyebabkan hambatan pertumbuhan embrio bahkan dapat mengakibatkan kematian (Phillot et al. 2006; Al-Bahry et al. 2011). Kematian embrio bermula dari lapisan cangkang yang dapat ditembus oleh mikroorganisme melalui poripori yang ada diseluruh permukaan cangkang. Rusaknya struktur lapisan cangkang telur merupakan awal penetrasi mikroorganisme untuk masuk dan berkolonisai ke dalam komponen telur (Yolk dan Albumin) (Al-Bahry et al. 2004).

Menurut Al-Bahri et al.. (2009), cangkang telur penyu terdiri dari 3 lapisan yaitu lapisan luar berkalsium, lapisan multistrata di tengah dan lapisan dalam. Lapisan luar terdiri dari nodular yang tidak terikat antara nodul satu dengan yang lainnya dan memiliki bentuk dan ukuran yang bervariasi. Unit-unit nodular ini terbentuk atas $\mathrm{CaCO}_{3}$ dalam bentuk aragonit (91\%), kalsit $(6 \%)$ dan verit (3\%). Lapisan tengah terdiri dari bahan amorf organik dengan aragonit (89\%) dan kalsit (11\%). Membran dalam terdiri dari serat retikular dengan kristal $\mathrm{NaCl}$. Banyaknya cemaran mikroorganisme yang berada di cangkang dari sampel TB maupun TS diduga bahwa keberadaan senyawa organik yang dimiliki cangkang telur tersebut menarik mikroorganisme untuk memanfaatkanya sebagai sumber nutrisi untuk hidup. Hal inilah yang menyebabkan telur gagal menetas.

\section{KESIMPULAN}

Hasil penelitian ini menunjukkan adanya cemaran mikroorganisme pada telur penyu sisik di Pulau Kelapa Dua. Analisis mikrobiologi membuktikan keberadaan mikroorganisme pencemar yang meliputi bakteri, jamur, coliform, Enterobacter, dan SalmonellaShigella pada seluruh sampel. Jumlah mikroorganisme tertinggi terdapat pada sampel telur dari sarang semi-alami yang gagal menetas (TB). Keberadaan mikroorganisme dapat berasal dari induk penyu maupun lingkungan penetasan atau sarang. Jumlah mikroorganisme sangat berpengaruh terhadap faktor penetasan telur. Pada jumlah yang relatif rendah tidak membahayakan embrio dalam telur, namun pada jumlah tingkat yang tinggi dapat menyebabkan telur gagal menetas atau mengalami kematian.

\section{SARAN}

Perlu dilakukan analisis mikrobiologi secara biokimia maupun biomolekuler untuk mengetahui jenis mikroorganisme pencemar pada telur penyu sisik di Pulau Kelapa Dua hingga tingkat spesies.

\section{DAFTAR PUSTAKA}

[1] Al-Bahry SN, Mahmoud IY, Al-Harthy A, Elshafie AE, Al-Ghafri S, Alkindi 
AYA, Al-Amri I. 2004.Bacterial Contamination in freshly laid egg green turtles Chelonia mydas at Ras Al Hadd reserve, Oman. In: 24th International Symposium for Sea Turtles. San Jose, Costa Rica.

[2] Al-Bahry S, Mahmoud I, Elshafie A, AlHarthy A, Al-Ghafri S, Al-Amri I, Alkindi A. 2009. Ultrastruktural features and elemental distribution in eggshell during pre and post hatching periods in the green turltle, Chelonia mydas at Ras Al-Hadd, Oman. Tiss Cell. 41:214-221.

[3] Al-Bahry S, Mahmoud I, Elshafie A, AlHarthy A, Al-Zadjali M, Al-Alawi W. 2011. Antibiotic resistant bacteria as bioindicator of polluted effluent in the green turtle, Chelonia mydas in Oman. Mar Envir Res. 71:139-144.

[4] Estika A. 2013. Analisis mikroorganisme pada telur penyu hijau (Chelonia mydas) dari Pulau Bilang-bilangan, Kalimantan Timur. Prosiding Seminar Nasional Biologi. UPI. Bandung.

[5] Foti M, Giacopello C, Bottari T, Fisichella V. Rinaldo D, Mammina C. 2009. Antibiotic resistance of gram negatives isolates from loggerhead sea turtle (Caretta caretta) in the central Mediteranian Sea. Mar Poll Bull. 58:1363-1366.

[6] Gans C \& Gaunt AS. 1969. Shell and physiology of turtles. Afr. Wildlife. 23:197-206.

[7] Janawi. 2009. Perkembangan Suhu Sarang Penetasan Buatan pada Penetasan Telur Penyu hijau (Chelonia mydas L.) di Pantai Pangumbahan Kabupatan Sukabumi. [skripsi]. Fakultas Pertanian Universitas Suryakencana. Cianjur.
[8] Keene . 2012. Microorganisms from Sand, Cloacal Fluid, and Eggs of Lepidochelys olivacea and Standard Testing of Cloacal Fluid Antimicrobial Propertie. Master Thesis. University of Indiana.

[9] Lam J. 2006. Levels of trace elements in green turtle eggs collected from Hong Kong. Environ Poll. 144:790-801.

[10] Nur N. 2004. Sea Turtle Conseation in Malaysia. www.wildasia.net (Diakses pada 30 Januari 2014].

[11] Rudiana E, Ismunarti D.H, Nirwani S. 2004. Tingkat Keberhasilan Penetasan dan Masa Inkubasi Telur Penyu Hijau, Chelonia mydas $L$ pada Perbedaan Waktu Pemindahan. Ilmu Kelautan.UNDIP. Semarang.

[12] Spotilla JR. 2004. Sea Turtles: A Complete Guide to Their Biology, Behavior, and Conservation. John Hopkins University. Baltimore.

[13] Suwelo IS, Widodo SR, Ating S. 1992. Penyu Sisik di Indonesia. LIPI Oseanografi. Jakarta. Jurnal Oseana. 17: 97-109.

[14] Syamsuni YF. 2006. Karakteristik Habitat dan Penyebaran Sarang Penyu sisik (Eretmochelys imbricata). [Skripsi]. Jurusan Ilmu Kelautan. Fakultas Perikanan dan Ilmu Kelautan. Institut Pertanian Bogor. Bogor.

[15] Phillott AD. 2002. Fungal colonization of sea turtle nests in estern australia. Ph.D Dissertation. Central Queensland University.

[16] Phillot AD, Parmenter CJ, McKillup SC. 2006. Calcium depletion of eggshell after fungal invasion of sea turtle eggs. Chelon Conserv Biol. 5:146-149. 